DOI https://doi.org/10.30525/978-9934-26-113-8-35

\title{
ПЕРСПЕКТИВИ ВИКОРИСТАННЯ RANUNCULUS ACRIS У ФАРМАЦIÏ
}

\author{
Юзьків С. Л. \\ студент кафедри технології біологічно активних сполук, \\ фармачії та біотехнології \\ Національний університет «Львівська політехніка»
}

Карпюк В. Р.

аспірант кафедри технології біологічно активних сполук, фармачії та біотехнологї

Національний університет «Львівська політехніка»

\section{Червецова В. Г.}

кандидат біологічних наук,

доцент кафедри технології біологічно активних сполук, фармаиії та біотехнологіі

Національний університет «Львівська політехніка»

\author{
Конечна Р. T. \\ кандидат фармачевтичних наук, \\ доиент кафедри технології біологічно активних сполук, \\ фармації та біотехнології \\ Національний університет «Львівська політехніка» \\ м. Львів, Украӥна
}

3 кожним роком набувають популярності лікарські засоби рослинного походження. Перспективною рослиною, яка використовується в народній медицині в багатьох країнах світу і при подальшому дослідженні може бути використана у фармацевтичній і біотехнологічній промисловості $є$ рослина родини Ranunculaceae (Жовтицеві) Ranunculus acris (Жовтець їдкий).

Метою нашого дослідження є аналіз сучасних літературних джерел та огляд актуальних наукових досліджень, щодо вивчення та застосування Ranunculus acris у фармації та біотехнології.

Ranunculus acris (Жовтець їдкий) - багаторічна трав'яниста рослина, що досягає у висоту 25-75 см. Прикореневі й нижні стеблові листки черешкові, п’ятикутні, пальчастороздільні, з видовженоромбічними част126 
ками, цілокраї або зубчасті; верхні листки - сидячі, трироздільні. Квітки одиничні, двостатеві, правильні, п'ятироздільні, 3 золотаво-жовтими блискучими пелюстками. Плід - збірний, із сім'янок, головчастий. Цвіте у травні - серпні. Розмножується як вегетативно, так і насінням. Росте на луках, лісових галявинах і узліссях майже по всій території України, крім південної частини Степу $[1,2]$.

Лікарською рослинною сировиною, що містить цінні біологічно активні речовини, є трава Ranunculus acris, яка містить алкалоїди (0,1\%), дубильні речовини $(2,6$ \%), $\gamma$-лактони (ранункулін, анемонін, протоанемонін), сапоніни, вітаміни (аскорбінова кислота, каротин), флавонові та серцеві глікозиди [1]. Квіти Raunculus acris містять похідні жирних кислот (гексилацетат, цис-3-гексенилізовалерат, цис-3-гексенілацетат, 2-гексенілацетат, цис-3-гексенол, гептанол, октанол, протоанемонін), ізопреноїди (монотерпени, цис- $\beta$-оцимен, транс- $\beta$-оцимен, транс- $\beta$ оцимен епоксид, оксид ліналуолу), сесквітерпени (гермакрен-D, каріофілен, $\beta$-селінен, $\alpha$-фарнезен, цис- $\alpha-$ бергамотен, транс- $\alpha$-бергамотен), бензеноїди (метоксибензол, метил 2-гідроксибензоат, 2-фенілетанол) [8].

Траву збирають під час цвітіння рослини у травні - червні. Рослина неофіцинальна.

Експериментальними дослідженнями та клінічними спостереженнями 3'ясовано, що рослина має антибактеріальні, антивірусні, антитоксичні, епітелізуючі та протитуберкульозні властивості.

Використовують жовтець в основному як зовнішній засіб для лікування ран, інфікованих дерматозів та туберкульозу шкіри. Внутрішньо, в невеликих дозах, відвар квіток використовували при захворюваннях печінки [1].

Жовтець їдкий використовується для лікування в народній медицині корінними американцями. Рослину використовують при абсцесах, сік використовують як заспокійливий засіб. Поширеним $є$ використання Ranunculus acris як знеболювального засобу при головних болях а також застосування настою коренів при проносі [4].

Ranunculus acris використовується в народній медицині і інших країн. Так, в Польщі, відвар листя застосовувався для лікування екземи [5]. В Казахстані, свіжа рослина використовується в гомеопатії при шкірних захворюваннях, подагрі, невралгії та туберкульозі [6]. Народна медицина Італії зазначає застосування рослини як блювотного засобу у разі отруєння [7].

Проте, слід пам'ятати і про застереження при використанні рослини, оскільки глікозиди, що входять до складу комплексу біологічно активних 
речовин викликають подразнення шкіри, почервоніння, свербіж і навіть набряки.

Висновок. Ranunculus acris має широкий спектр застосування в народній медицині і містить різноманітний хімічний склад. Враховуючи вище сказане, Ranunculus acris при подальшому дослідженні може бути використана у фармацевтичній і біотехнологічній промисловості.

\section{Література:}

1. Жовтець їдкий // Лікарські рослини : енциклопедичний довідник / за ред. А. М. Гродзінського. Київ : Видавництво «Українська Енциклопедія» ім. М. П. Бажана, Український виробничо-комерційний центр «Олімп», 1992. С. 162.

2. Harper, J. L. Ranunculus Acris L. The Journal of Ecology, Vol. 45, No. 1 (Apr., 1957), P. 289.

3. Проничкина А. А., Лебедев А. Н. Сорные лекарственные растения Средней полосы европейской части России. Лікарське рослинництво: від досвіду минулого до новітніх технологій: праці 2 міжнар. наук.-практ. інтернет-конф. (Полтава, 15-16 травня 2014 р.). Полтава, 2014. С. 63.

4. Ranunculus acris // Wikipedia, the free encyclopedia. URL: https://en.wikipedia.org/wiki/Ranunculus_acris (дата звернення 28.06.2021).

5. Jaskier ostry // Wikipedia, wolna encyklopedia. URL: https://pl.wikipedia.org/wiki/Jaskier_ostry

6. Павлов Н. В. Растительное сырьё Казахстана. М., 1947

7. https://it.wikipedia.org/wiki/Ranunculus_acris\#Usi Ranunculus acris // Da Wikipedia, l'enciclopedia libera. URL: https://it.wikipedia.org/wiki/ Ranunculus_acris\#Usi_(дата звернення 28.06.2021).

8. Bergström, G., H. E. M. Dobson, I. Groth. 1995. Spatial fragrance patterns within the flowers of Ranunculus acris (Ranunculaceae). Plant Systematics and Evolution, 195 (3-4), 221-242. 